\title{
Teaching Mathematics in Early Childhood Education with ICT: The Views of Two Contrasting Teachers' Groups
}

\author{
Artemis Eleftheriadi ${ }^{1}$, Konstantinos Lavidas ${ }^{2^{*}}$, Vassilis Komis ${ }^{3}$
}

\begin{abstract}
${ }^{1}$ Postgraduate student in Department of Educational Sciences and Early Childhood Education, University of Patras, GREECE
${ }^{2}$ Laboratory and Teaching Staff Department of Educational Sciences \& Early Childhood Education University of Patras, GREECE

${ }^{3}$ Professor, Department of Educational Sciences and Early Childhood Education, University of Patras, GREECE

*Corresponding Author: lavidas@upatras.gr
\end{abstract}

Citation: Eleftheriadi, A., Lavidas, K., \& Komis, V. (2021). Teaching Mathematics in Early Childhood Education with ICT: The Views of Two Contrasting Teachers' Groups. Journal of Digital Educational Technology, 1(1), ep2103. https://doi.org/10.21601/jdet/11117

\section{ARTICLE INFO}

Received: 2 Jun. 2021

Accepted: 12 Jul. 2021

\begin{abstract}
The aim of this study is to compare the views of preschool teachers using ICT to those who do not, on the basis of the benefits and the barriers that ICT bring in teaching and learning mathematics. Twenty preschool teachers took part in this study: nine who do not use ICT and eleven, who do use them for teaching mathematics. Data were collected with semi-structured interviews and analyzed using the thematic content analysis method. Results indicate that preschool teachers, who use ICT in teaching mathematics, teach mathematical concepts such as spatio-temporal, orientation, classification, matching, serializations, quantities, mathematical operations, patterns, comparisons, volume, shapes, and size. Moreover, despite the benefits of ICT observed by teachers of both groups, but mainly from the one using ICT, the overall use of ICT in the teaching of mathematics is obsoleted. The main barriers of ICT integration, according to preschool teachers are the lack of training on its integration and the preschool teachers' role during the teaching of mathematics. Implications for in-service teacher training and educational policy are discussed.
\end{abstract}

Keywords: use of ICT, teaching mathematics, kindergarten, early childhood education, thematic content analysis, Greece

\section{INTRODUCTION}

The rapid development of Information and Communication Technologies (ICT), in recent years, has brought significant developments in global education systems (Dooley et al., 2014). New generation, coming into contact with technologies from a very early age, become accustomed and learn quickly (Liu et al., 2014). According to the National Council for Educational Mathematics (NCTM, 2015), technology is an integral part of encouraging mathematical skills in kindergarten as well. Toddlers can develop their critical and creative scientific thinking, as well as their interest in mathematics (Clements \& Sarama 2016; Dooley et al. 2014). ICTs can support communication, collaboration, creativity, and the development of mathematical skills in toddlers too (Calder, 2015; Nikolopoulou, 2014; Papadakis et al., 2018).

From all the levels of education, the integration of ICT is more favored in the preschool (Sabanci \& Omeroglu, 2015). It is then that preschool teachers get to know their students better because they spend many hours a day with them and at the same time, they are not pressured to complete the curriculum (Papadakis, 2015). However, although preschool teachers state their willingness to use ICT in teaching and learning in various subjects (Sanchez et al., 2012), them using of ICT for teaching mathematics is quite limited too (Clements, 2002; Nikolopoulou, 2020). Similarly, research examining preschool teachers' views on the use of ICT in teaching and learning, especially in mathematics, is quite limited (Clements, 2002; Fox et al., 2016).

In the present study we try to record the views of preschool teachers about the usage, the benefits, and the barriers of ICT for teaching of mathematics in the class. More specifically and as stated earlier, we aim to understand the gap between those who use ICT and those who do not when teaching mathematics. Teachers' views are particularly important, because they decide on the use and integration of ICT in the teaching of mathematics and as key members, they support the educational process. This research study seeks to provide insight into the reasons behind the low integration of ICT in the teaching of mathematics. 


\section{LITERATURE REVIEW}

Teaching mathematics is an integral part of the Greek preschool curriculum. The aim of the curriculum is to help children expand their basic mathematical knowledge and practice new, within an experiential and interdisciplinary context. Furthermore, the toddlers with the method of trying and testing, are able to process new data and calculate simple mathematical equations. In addition to that, by using modern technology, they are able to solve problems, recognize numbers on the keyboard and understand the importance of calculators and digital tools in everyday life. The integration of ICT to the Greek preschool curriculum, helps the toddlers to compare, count and recognize objects or shapes of their surroundings ("A cross thematic curriculum framework", 2003).

Research worldwide highlights the importance of the use of ICT in kindergarten, through experimental teaching interventions (Dooley et al., 2014; Plowman \& Stephen, 2005). Using a variety of technological tools, such as computers, tablets, laptops, smartphones, and educational software, researchers support many benefits for learning mathematics (Clements, 2002; Papadakis et al., 2018; Zaranis \& Valla, 2019). With the assistance of ICT, the teaching of numeracy and geometric knowledge and skills are supported (Clements, 2002; Papadakis et al., 2018) and mathematical thinking is cultivated (Clements, 2002; Zaranis, 2014). ICT mainly contributes to the development of mathematical concepts and skills, such as understanding and improving of number sense, the counting, relating an object to each count as well as, classification, serialization and matching (Nikolopoulou, 2020; Papadakis, 2015; Zaranis \& Valla, 2019). In addition to the positive learning effects of ICT in the teaching of mathematics, research often mentions the positive emotions that children develop as a result. Toddlers get excited and attracted by the graphics, the playful form, maintaining their undiminished interest and enhancing their concentration (Nikolopoulou, 2020; Zaranis, 2014; Zaranis \&Valla, 2019).

Empirical research conducted worldwide on the views of preschool teachers around ICT integration and its use in teaching and learning of mathematics is limited (Ihmeideh \& Al-Maadadi, 2018; Sabanci \& Omeroglu, 2015). As a rule in kindergarten, we meet two common categories. According to Kerckaert et al. (2015), ICT use in preschool supporting mainly basic ICT skills and is used less as a tool for supporting contents and individual learning needs, thus advancing education and learning. The findings from the study in Qatar (Ihmeideh \& Al-Maadadi, 2018) agree with this finding, i.e., that preschool teachers use computers primarily for listening to songs and make less use of drill and practice software for language and mathematics. This way, each child completes the given activity themselves following specific teachers' instructions (Ihmeideh \& Al-Maadadi, 2018). In Greece, research conducted on the subject is also very limited with a few findings presented around teachers' views on the use of educational software in modern Greek kindergartens for mathematic purposes (Liu et al., 2014; Nikolopoulou, 2014; Nikolopoulou, 2020). Specifically, in the Greek classrooms of kindergartens, teachers use ICT more for the preparation of teaching and less for educational purposes (Liu et al., 2014;
Nikolopoulou, 2020). Particularly for educational purposes, teachers use ICT as an information search means and as a complementary and supportive tool, to view educational videos or pictures as well as for listening to songs, and to improve students' mathematics knowledge and skills (Nikolopoulou, 2020; Romero-Tena et al., 2020). Furthermore, its use takes place during free activities, while the computer occupation choice is more often made by students (Nikolopoulou, 2020).

It is well established that teachers face various barriers in using ICT in teaching and learning including mathematics (Fox et al., 2016). These barriers are classified into external and internal barriers (Ertmer et al., 1999). External barriers seem to dominate the findings of many studies. Some of these are the lack of training of preschool teachers, the rare technical support, as there are no computer technicians in the school to support teachers (Fox et al., 2016; Nikolopoulou \& Gialamas 2015; Sanchez et al., 2012) and the lack of funding for Greek kindergartens (Nikolopoulou \& Gialamas, 2015). Internal barriers concern personal issues presented by teachers are lack of knowledge, but also the belief of computers not being a core activity and should not be given priority (Fox et al., 2016; Ljung-Djärf et al., 2005; Sanchez et al., 2012).

\section{RESEARCH OBJECTIVE}

In reality, research does not satisfactorily reflect the utilization of ICT for the teaching of mathematics in kindergarten. There are only a few studies that highlight the ways of integrating ICT as well as the factors that hinder its smooth integration in preschool mathematics teaching (Fox et al., 2016; Ihmeideh \& Al-Maadadi, 2018; Nikolopoulou, 2020). The need to capture reality necessitates recording of preschool teachers' views on the actual conditions and practices applicable in the case of Greek kindergartens. This research aims to compare the views of preschool teachers who use or do not use ICT for teaching mathematics, for the use, benefits, and barriers of using ICT in teaching and learning mathematics. The findings of this research will highlight the distance to be covered, i.e., the support yet to be provided to preschool teachers so that the use of ICT in the teaching and learning of mathematics can be expanded.

\section{METHODOLOGY}

\section{Design}

In this research we chose to examine two contrasting cases. This qualitative comparative method allows researchers to analyze facts holistically and in depth, as they are experienced by two "contrasting" groups (Bryman, 2016). It's been already stated but to elaborate, our focus groups are: "Group TA" which is preschool teachers not using ICT to teach mathematics in kindergarten and "Group TB" which contains using it. The comparative study of these two groups allows highlighting the common and different elements of the cases (Bryman, 2016). 
Table 1. Demographic characteristics of the sample and characteristics of settings

\begin{tabular}{|c|c|c|c|c|}
\hline Teacher code & Years of teaching experience & Number of children in class & Training in teaching mathematics & ICT training \\
\hline TA1 & Up to 10 & 25 & No & No \\
\hline TA2 & $16-20$ & 28 & Yes & Yes \\
\hline TA3 & 11-15 & 24 & Yes & Yes \\
\hline TA4 & Up to 10 & 25 & No & Yes \\
\hline TA5 & $20+$ & 17 & No & Yes \\
\hline TA6 & $20+$ & 17 & No & Yes \\
\hline TA7 & Up to 10 & 21 & No & No \\
\hline TA8 & Up to 10 & 25 & No & Yes \\
\hline TA9 & $16-20$ & 21 & No & No \\
\hline TB1 & Up to 10 & 18 & No & No \\
\hline TB2 & $16-20$ & 21 & Yes & Yes \\
\hline TB3 & $20+$ & 14 & No & Yes \\
\hline TB4 & $16-20$ & 20 & No & Yes \\
\hline TB5 & $11-15$ & 16 & No & No \\
\hline TB7 & Up to 10 & 25 & No & No \\
\hline TB8 & $20+$ & 14 & Yes & Yes \\
\hline TB9 & $20+$ & 20 & Yes & Yes \\
\hline TB10 & Up to 10 & 21 & No & No \\
\hline TB11 & Up to 10 & 15 & No & No \\
\hline
\end{tabular}

Notes: TA: Teachers not using ICT for teaching mathematics and TB: Teachers using ICT for teaching mathematics

\section{Sample}

We use purposive sampling. More specifically we asked the Regional Directorate of Education of the South Aegean for Preschool teachers to nominate teachers from the South Aegean region who do not use ICT to teach mathematics and others who use them. Out of them, 15 from Group TA and 14 from Group TB agreed to participate. The interviews were conducted until data saturation was achieved in each group separately. Thus, the final sample (Table 1 ) included 20 female preschool teachers, nine from Group TA ( 8 and 1 from public and private school respectively) and 11 from Group TB (10 and 1 from public and private school respectively). All preschool teachers had one or two computers that had access to the Internet in their classrooms. Teachers in both groups had a similar distribution in terms of years of teaching experience, number of children in class and their training in teaching mathematics and ICT use.

\section{Research Instrument and Procedure}

Semi-structured interviews with preschool teachers were carried out to identify the practices they followed on this matter. The interviews were conducted on an individual basis and the interview protocol was based on the purpose of the research. Initially, the interview protocol was applied on a pilot sample of two teachers, one from each group (Group TA and Group TB), to determine any development areas and make appropriate revisions. Those preschool teachers were not included in the final sample. The finalized interview protocol included 18 questions, divided into four categories (see Appendix). In the first category, teachers were asked to present their teaching practices regarding mathematics while mentioning the mathematical concepts they teach and their frequency in any given week. In the second one, they were asked to indicate the technological environment generally but also specifically for the teaching of mathematics and mathematical concepts through ICT. We then asked those who used educational software to teach mathematics to describe an approach they have implemented using ICT. In the last two categories, we attempted to capture the learning benefits and barriers which were observed by the preschool teachers, when using ICT in the teaching of mathematics.

The semi-structured interviews were conducted between September and October 2020 by telephone, because physical interviews were not feasible due to COVID-19 spread restriction measures. Prior to conducting the study, we received approval from the Research Ethics Board designated by the University of Patras and particularly from the Department of Educational Science and Early Childhood Education. In preparation for the interview, we explained the aims of the research to the teachers, asked for their consent to participate. Their permission requested to record the interview process, assuring any personal data would stay anonymous for the sake of this research. Moreover, before the analysis of their responses, we allowed the teachers to read the interview transcripts and asked for their further consent for its inclusion in the data analysis. Each interview lasted approximately 10 to 15 minutes and the corresponding transcript lasted 50 to 60 minutes.

\section{Data Analysis}

Qualitative data were analyzed using the thematic content analysis method (Bryman, 2016) to develop relevant codes, categories, and topics. All interviews were recorded verbatim and read in an order that gave an overview of the participants' views. Their views were broken down into distinct points always around a central focus, i.e., the subject of this study (for example see Figure 1). These points became codes, which turned into categories, and then formed our themes. 


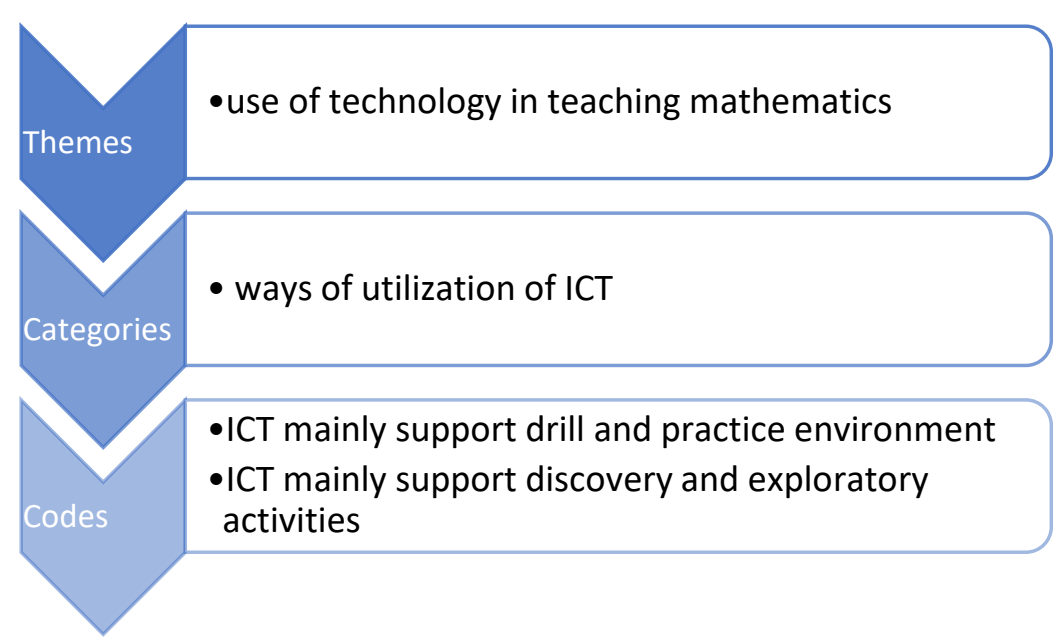

Figure 1. Example of coding in the analysis of interviews (Adapted by Tsirmpa et al., 2021)

\section{RESULTS}

In the following part of this study, we present the results of the analysis of the interviews comparatively for the two groups of teachers based on the four interview categories.

\section{Teaching Mathematics}

Throughout the interviews it was observed that all preschool teachers teach mathematics in their classroom exactly as defined by the curriculum, either in routines or in organized activities while always considering the children's abilities in every class. All teachers stated that they primarily follow the order of the curriculum for the teaching of mathematical concepts. Specifically, a teacher stated that:

TA6: "[...] in autumn we start with the spatio-temporal concepts, up, down, inside, outside, many, few, more, less. Depending on the level of the children we introduce the concept of number and population, i.e. 1, 2, 3. Usually, we teach these concepts until Christmas. Then we continue with the other numbers and other concepts such as classifications, matching, serializations, regular numbers, absolute numbers, arithmetic, first and last. Through them we work at the same time the colors and the shapes, solid and flat". Also, another teacher stated:

TB4: “[...] everything is taught according to their degree of difficulty, from the easiest to the most difficult".

Also, the implementation of organized activities for mathematics seemed to depend on the interest of teachers for mathematics. For example:

TB2: “[...] mathematics is an area that I did not prefer and so while mathematics integrated into daily routines, organized activities for mathematics will become less frequent compared to other areas, such as language".

Finally, preschool teachers who feel more confident with mathematics will automatically organize more regular mathematical activities, three or even four times a week.

\section{ICT Integration in Class for Teaching Mathematics}

In the next part, we attempt to capture further information on the use of ICT in kindergarten for teaching mathematics. Teachers stated that they use computers and mobile devices. Table 2 presents the most popular educational software, the types of ICT use and the mathematical concepts taught. Interestingly enough, the statements of two teachers TA2 and TA4 were that the use of educational software was part of their teaching in the midst of the pandemic and e-learning. The educational software was the only tool that allowed them to interact with children and so they were more motivated to use it.

TA4: “[...] last year, due to the overall circumstances, I started using some educational software, such as Learning apps, Jigsaw planet, and the Photodendro".

Nevertheless, when we asked what the mathematical concepts were taught with this software, she revealed that:

TA4: “[...] the ministry’s instructions were vague and didn’t serve specific purposes”.

However, there were two teachers TA1 and TA5 who were not aware of any educational software and therefore were not familiar of the ways they could use ICT during the educational process. Teachers in Group $\mathrm{TB}$ seem to be equally knowledgeable of the same software used to teach mathematics with teachers in Group TA for other subjects. The fact raises questions on the reasons of the lack of use of these educational software similarly as Group TB (This fact is explained below).

Regarding the types of use of the educational software for the teaching of mathematics, the preschool teachers of Group TB, mentioned that they use them either as a tool of drill and practice or as a tool for discovery and exploratory activities, indicative excerpt:

TB4: “[...] activities with the use of software are not the initial activities. First, we do something experiential in the corner of the class where we all gather together either individually or in groups and then we move on to the digital part. We mainly use drill and practice 
Table 2. Teachers' use of ICT for teaching mathematics

\begin{tabular}{|c|c|c|}
\hline & TA Group & TB Group \\
\hline $\begin{array}{l}\text { Digital } \\
\text { educational } \\
\text { environment }\end{array}$ & $\begin{array}{l}\text { Youtube (6), MS Paint (3), MS Word (3), Learning } \\
\text { apps (2), KIDePEDIA(2), Tux Paint (1), Hot } \\
\text { potatoe (1), RAMKID (1), Aerostat (1), GCompris } \\
\text { (1), Jigsaw planet (1), Photodendro (1), } \\
\text { Electronic Postman (1) }\end{array}$ & $\begin{array}{l}\text { Youtube (6), Tux Paint (6), Bee-Bot (5), MS Word (4), MS PowerPoint (4), } \\
\text { Learning apps (4), KIDePEDIA (3), Photodendro (3), Jigsaw planet (3), } \\
\text { Wordwall (3), Kidspiration (2), Google maps (2), RNA(1), Google kids (1), } \\
\text { ABC ya (1), Explore the computer (1), Myself and the others (1), RAMKID } \\
\text { (1), The strange journey of Foundoulis (1), Google Earth (1), Aerostat (1) }\end{array}$ \\
\hline $\begin{array}{l}\text { Digital } \\
\text { educational } \\
\text { environment for } \\
\text { mathematics }\end{array}$ & Not use & $\begin{array}{l}\text { Bee-Bot (5), Photodendro (5), Learning apps (5), KIDePEDIA (3), Google } \\
\text { maps (2), The adventures of Savvy (2), Wordwall (2), Tux math (2) Scratch } \\
\text { (1), ABC ya (1), Kids first coding \& robotics (1), Aerostat (1) }\end{array}$ \\
\hline $\begin{array}{c}\text { Ways of } \\
\text { utilization }\end{array}$ & Not use & Drill and practice (9), Support discovery and exploratory activities (4) \\
\hline $\begin{array}{l}\text { Mathematical } \\
\text { concepts taught }\end{array}$ & Not use & $\begin{array}{c}\text { Numbers/counting (11), Spatio-temporal concepts (10), Orientation (10), } \\
\text { Matches (8), Shapes (8), Quantities (7), Operations (7), Classification (7), } \\
\text { Serialization (7), Size (6), Speed /distance (5), Length (5), Volume (3), Dual } \\
\text { input tables (3), Patterns (3) }\end{array}$ \\
\hline
\end{tabular}

Notes: TA Group, Teachers who do not use ICT for teaching mathematics,

TB Group, Teachers using ICT for teaching mathematics. In the parentheses present the number of teachers in each case.

software and much less often we use ICT as an occasion to start an activity".

Only two of our preschool teacher's sample mentioned that they use ICT as a teaching supporting tool. For example:

TB7: "[...] in an effort to teach the rectangle shape and length, I first made a floor for Bee-Bot, the same as the one in the software. For the rectangle, the toddlers took the tongue depressors and measured for example that the vertical is 2 tongue depressors and the horizontal is 6.Or, they counted how many steps does the Bee-Bot have to take to form the rectangle, how many for the horizontal line, and how many for the vertical one”.

TB2: “...Recently, because we wanted to do some distance measurement activities, we screened a French film, 'The Red Balloon', the toddlers became online friends with the film's hero on a fantasy level and measured the distance from our school to Paris with the help of Google maps and then we transferred this distance to the globe with a rope."

Regarding the category of mathematical concepts taught as these were stated by the teachers that they teach with the educational software, the preschool teachers, Group TB quoted the spatio-temporal concepts, of forward / backward, right / left, matching, quantities, sorting, serialization, size, volume, length, mathematical operations, dual input arrays, speed/distance and even shapes (TB2, TB3, TB4). According to them, these concepts were taught with the help of Google maps, Learning apps, $\mathrm{ABC}$ ya, Kids first coding \& robotics. It was characteristically mentioned that:

TB5: “[...] almost all mathematical concepts can be taught with the support of educational software. The toddlers come in contact with numbers, with the operations of subtraction and addition".

In another excerpt, although the preschool teacher TB6 does not use a variety of software apart from, KIDePEDIA and RAMKID, we asked her if this software supported her in teaching mathematical concepts and she stated that:
TB6: “[...] I use some games as they contain some premathematical concepts, such as orientation concepts or space-time concepts, matching, serialization, and numbers".

\section{Benefits of the Utilization of ICT in Teaching Mathematics}

All the preschool teachers using ICT for the teaching of mathematics agreed on the benefits that ICT can offer regarding mathematics but also on the undiminished interest and concentration of children on the task, due to the attractive form of ICT as it is presented on Table 3. Preschool teacher TB2 described how the children, after being taught distance and speed with the support of Google maps, made reductions and references to other examples of their daily lives, making new measurements and assumptions on their own. Similar estimates were made by other preschool teachers who reported that ICT supports children in understanding pre-mathematical concepts and consolidating matching with quantities, measuring length, meanings of shapes and numbers and developing their memory skills. Overall, teachers (TB3, TB7 and TB5) recognize that these tools manage to gain the attention of toddlers, intensify their concentration and therefore record more positive and greater results in terms of completion and success of a task. In fact, teachers claim that software has become part of their daily routine and at the same time acts as a playful way of teaching. In addition, children are given an incentive to engage, due to their pleasant and attractive form. Indicatively, a preschool teacher states:

TB5: “[...] kids love software because of the sounds and dynamic images that better support the exploration of mathematical concepts than static images. We certainly noticed a learning benefit, but the way the children dealt with them showed their interest more. With static images, they can get bored much faster or feel frustrated and give up more easily and this is not because of a lack of perception, but because they are not carried away by the process that has no movement". 
Table 3. Benefits of ICT use in teaching mathematics

\begin{tabular}{lcc}
\hline & TA Group & TB Group \\
\hline $\begin{array}{c}\text { Useful to children with } \\
\text { concentrating and cooperating for kids } \\
\text { difficulties (1) }\end{array}$ & $\begin{array}{c}\text { Enthusiasm (10), Encourage children's engagement (10), Better understanding of } \\
\text { mathematical concepts (9), Effective tools for learning through play (9), Children enjoy } \\
\text { using educational software (9), Increased engagement (9), Give children motivation to } \\
\text { participate (9), Better approach to a math concept than a worksheet (5) }\end{array}$ \\
$\begin{array}{c}\text { Notes: TA Group, Teachers who do not use ICT for teaching mathematics, } \\
\text { TB Group, Teachers using ICT for teaching mathematics. In the parentheses present the number of teachers in each case. }\end{array}$ \\
\begin{tabular}{ccc} 
Table 4. Barriers of ICT integration for teaching mathematics & TB Group \\
\hline Tack of training for using ICT (6), Large number of \\
children in classrooms (5), Lack of technological \\
infrastructure (5), Lack of technical support (1)
\end{tabular} \\
\hline $\begin{array}{c}\text { Lack of knowledge (7), Preferences for “hands-on” } \\
\text { teaching methods (2) }\end{array}$ & $\begin{array}{c}\text { Lack of training for using ICT (8), } \\
\text { Internal }\end{array}$
\end{tabular}

Notes: TA Group, Teachers not using ICT for teaching mathematics, TB Group, Teachers who use ICT for teaching mathematics.

Regarding Group TA, only one teacher (TA4) reported benefits from this. In particular, she said that their use could be useful to children who have difficulty concentrating and cooperating.

\section{Barriers to the Use of ICT in Teaching Mathematics}

The responses of teachers of both groups regarding the barriers to the integration of ICT in teaching mathematics were varied. All reported barriers were classified into subcategories (external and internal) as they are presented in Table 4. It is important to mention that most of the barriers that teachers stated were external. Teachers, regardless the group they belonged to, expressed in different ways the need for their training regarding the use of ICT. For example, from the Group TA, the preschool teacher TA3 stressed that the teaching of mathematics through the use of educational software presupposes the training of teachers and the existence of appropriate equipment. In another excerpt, the teacher TA2 explained that it is difficult for her to understand her role using ICT in terms of having an active or passive participation or purely a guidance role, while she stressed that the children's employment with the computer is a personal situation, where only the toddler is involved and not the teacher. In her opinion, she does not contribute somewhere in this process, therefore it cannot be considered as integration in the educational process. At the same time, most of the TB group teachers reported that they only use drill and practice educational software and do not use ICT to support discovery and exploratory activities, as they do not know how this can be achieved in practice. In addition, two preschool teachers from TB group (TB9, TB10) mentioned that the using of ICT requires time for preparation.

The large number of children in kindergarten classes and the limited technological infrastructure are significant external barriers to the teaching of mathematics with ICT. Two preschool teachers, TA1 and TA5, discussed the supervision and occupation of the other children who do not work on the computer while the digital activity is happening (as a reminder, in the kindergartens there are only 1-2 computers per class), as a major issue in using educational software. For example, it was reported that:
TA4: “[...] a different classroom structure is needed in order to make effective use of educational software, because, with this large number of children and only one teacher in the classroom, it is challenging to keep other children busy at the same time, thus making it difficult to use the new technology".

When it comes to internal barriers, preschool teachers' preferences and knowledge appear to significantly affect the use of ICT in the teaching of mathematics. The analysis of the interviews revealed that some teachers prefer and support experiential learning which means that they give a priority to it, leaving behind the development of digital skills. For example, a teacher (TA group) stated that:

TA6: “[...] time is limited so, I give priority to other activities of my choice, such as psychomotor, where we know our body, play a lot of puppetry, involve children to develop their speech, and prefer role-playing games. I do not use educational software for teaching mathematics, because I prefer to work with our hands".

Furthermore, the analysis of the interviews of two preschool teachers (TA1, TA5) revealed ignorance of available educational software, which leads to the lack of it use during the educational process. Similarly, from the TB group, TB5 and TB6 teachers use obsolete software and find it difficult to integrate this into mathematics teaching, due to the small variety of activities they have, thus covering a small range of mathematical concepts.

\section{DISCUSSION AND CONCLUSION}

The aim of the research was to compare the views of two groups of preschool teachers, Group TA, who does not use ICT in teaching and learning mathematics and Group TB who use ICT for this purpose.

Regarding the overall teaching of mathematics in kindergarten, it seems that the preschool teachers followed the curriculum of mathematics, since they teach according to the instructions of the ministry, in both routines, and in organized activities. The responses analyzed for this study 
were consistent with Linder et al. (2011), who explain that preschool teachers in order to make meaningful connections to mathematical concepts, they embed learning experiences in the daily routine that engage young children in real-life activities.

Regarding the use of educational software, the two groups provided us with variable answers. Specifically, Group TA used educational software rarely and mainly for viewing or searching for information while they did not prefer them for teaching mathematics (Ljung-Djärf et al., 2005; Romero-Tena et al., 2020). In addition, teachers use educational software to teach mathematics in two common ways: more as a drill and practice tool and less as a tool of supporting discovery and exploratory activities (Clements, 2000; Ihmeideh \& AlMaadadi, 2018; Nikolopoulou, 2020). To elaborate more on this, according to our preschool teachers' sample, they teach mathematical concepts such as spatio-temporal, orientation, classification, matching, serializations, quantities, mathematical operations, patterns, comparisons, dual input tables, volume, shapes, and size (Liu et al., 2014; Nikolopoulou, 2020; Zaranis \& Valla, 2019). Moreover, they use educational software such as Google maps, learning apps, $\mathrm{ABC}$ ya, Kids first coding \& robotics to teach them. They also use various technological devices, such as computers, tablets, and robotic applications such as Bee-Bot.

Preschool teachers who use ICT to teach mathematics have noticed more intense involvement of toddlers in their engagement with digital mathematical activities. This involvement is mainly attributed to the attractive and playful form of digital environments, which can enhance toddlers' self-esteem and confidence (Gray et al., 2017; Liu et al., 2014). In some cases, preschool teachers distinguish more satisfactory learning outcomes because ICT takes into account the individual learning differences of children and support toddlers with learning difficulties; this is something that other researchers have supported (Calder, 2015; Kara \& Cagiltay, 2017; Outhwaite et al., 2017; Papadakis et al., 2018; Zaranis \& Valla, 2019).

The most important factor behind the barriers in using in teaching mathematics, according to the responses of our sample, was the lack of training on the integration of ICT and on their role in teaching mathematics. Group TA made frequent references to the large number of children in the classrooms in combination with the lack of technological infrastructure. The same group also mentioned internal barriers such as their preferences for experiential methods of teaching mathematics, their preferences for other lessons but also their limited knowledge in using ICT for teaching mathematics. The findings were consistent with previous studies (Fox et al., 2016; Gialamas \& Nikolopoulou, 2010; Kerckaert et al., 2015; Nikolopoulou \& Gialamas, 2015; Sanchez et al., 2012) which present teachers' preferences, lack of educational resources and training as the most important barriers expressed by preschool teachers.

\section{IMPLICATIONS AND LIMITATIONS}

The research findings observed that 6 of the 9 teachers, who do not use ICT to teach mathematics, while trained in doing so, do not use educational software to teach mathematics. Also, 1 out of 11 teachers who use ICT to teach mathematics, while has the certification to use ICT, only uses an old software to teach some pre-mathematical concepts. The other 9 out of 11 preschool teachers of Group TB use ICT for mainly drill and practice software and only two of them use ICT to support discovery and exploratory activities. Moreover, teachers from Group TA primarily highlighted internal barriers such as their beliefs and attitudes regarding the integration of ICT in the educational process. They also admitted that they prefer experiential teaching methods. This exhibits the need to create training programs regarding the benefits of ICT to shift their beliefs while strengthening their motivations for integrating ICT in the teaching and learning of mathematics (Fox et al., 2016; Kara \& Cagiltay, 2017).

In other words, it is proposed to implement a training to "bridge the gap" between the two teacher groups and to present proposals for a more beneficial use of ICT in the teaching of mathematics for all teachers. During this training, there should be presented proposals for technological advancement of teaching mathematics (e.g., with new digital environments for the teaching of mathematical concepts). Also, the training should elaborate on suitable approaches to the evolved role of the teacher and the way ICT is to be used for these purposes and through appropriate activities (Nikolopoulou et al., 2021; Theodoropoulou et al., 2021). As a result, the team of preschool teachers who do not use ICT to teach mathematics will be familiarized with this approach. Simultaneously, the preschool teachers group using ICT will be encouraged to examine and experiment with new ways of integrating ICT in educational toddlers. In addition, they will not only be limited to the drill and practice environments but will be exploring the discovery and exploratory learnercentered approaches (Lavidas et al., 2021). Finally, preschool teachers pointed out to us that the Government and Ministry of Education must support the technological infrastructure within kindergartens, fully equipping them across the country while providing technical support to each school unit.

We recognize as a limitation of this research the small sample size and therefore the difficulty of generalizing the research findings. Moreover, the fact that volunteers' respondents who participated in our study were asked to present their personal views on ICT is an issue as it usually leads to biased responses (Lavidas \& Gialamas, 2019). Further research is required on teachers' views on how to use ICT teaching mathematics in kindergarten and discovering new ways to minimize the barriers of its use. Finally, new technologies are part of the reality that new students are born into. They are native speakers of a digital language, so teacher must navigate them towards better ways of use ICT so they develop social and learning skills that respond to modern models of dynamic learning. Technology itself cannot make a difference unless society invests in teachers' knowledge and skills development.

Author contributions: All co-authors have involved in all stages of this study while preparing the final version. They all agree with the results and conclusions.

Funding: No external funding is received for this article.

Declaration of interest: The authors declare that they have no competing interests. 
Ethics approval and consent to participate: Prior to conducting the study, the researchers received approval from both the preschool teachers and Research Ethics Board designated by the Department of Educational Science and Early Childhood Education.

Availability of data and materials: All data generated or analyzed during this study are available for sharing when appropriate request is directed to corresponding author.

\section{REFERENCES}

A cross thematic curriculum framework (2003). http://www.pischools.gr/programs/depps/

Bryman, A. (2016). Social research methods. Oxford University Press.

Calder, N. (2015). Apps: Appropriate, applicable and appealing? In T. Lowrie, \& R. Jorgensen (Zevenbergen) (Eds.) Digital Games and Mathematics Learning. Mathematics Education in the Digital Era, 4, 233-250. https://doi.org/10.1007/978-94-017-9517-3_12

Clements, D. (2000). From exercises and tasks to problems and projects- unique contributions of computers to innovative mathematics education. Journal of Mathematical Behaviour, 19(1), 9-47. https://doi.org/10.1016/S0732-3123(00)000365

Clements, D. (2002). Computers in early childhood mathematics. Contemporary Issues in Early Childhood, 3(2), 160-181. https://doi.org/10.2304/ciec.2002.3.2.2

Clements, D., \& Sarama, J. (2016). Math, science and technology in the early grades. The Future of Children, 26(2). https://doi.org/10.1353/foc.2016.0013

Dooley, T., Dunphy, E., Shiel, G., Butler, D., Corcoran, D., Farrell, T., NicMhuira, S., O’Connor, M., Travers, J., \& Perry, B. (2014). Mathematics in early childhood and primary education (3-8 years): Teaching and learning. National Council for Curriculum and Assessment. https://ncca.ie/media/2147/ncca_research_report_18.pdf

Ertmer, P., Addison, P., Lane, M., Ross, E., \& Woods, D. (1999). Examining teachers' beliefs about the role of technology in the elementary classroom. Journal of Research on Computing in Education, 32(1), 54-72. https://doi.org/10.1080/08886504.1999.10782269

Fox, J., Diezmann, C., \& Lamb, J. (2016). Early childhood teachers' integration of ICTs: Intrinsic and extrinsic barriers. In B. White, M. Chinnappan, \& S. Trenholm (Eds.), Opening up mathematics education research (pp. 246-253). Proceedings of the $39^{\text {th }}$ annual conference of the mathematics education research group of Australasia. https:/files.eric.ed.gov/fulltext/ED572411.pdf

Gialamas, V., \& Nikolopoulou, K. (2010). In-service and preservice early childhood teachers' views and intentions about ICT use in early childhood settings: A comparative study. Computers \& Education, 55, 33-34. https://doi.org/10.1016/j.compedu.2010.01.019
Gray, C., Dunn, J., Moffert, P., \& Mitchell, D. (2017). Mobile devices in early learning: Evaluating the use of portable devices to support young children's learning. Report Commissioned by Irish Education Authority. https://doi.org/10.13140/RG.2.2.15948.82568

Ihmeideh, F., \& Al-Maadadi, F. (2018). Towards improving kindergarten teachers' practices regarding the integration of ICT into early years settings. The Asia - Pacific Education Researcher, 27, 65-78. https://doi.org/10.1007/s40299-0170366-X

Kara, N., \& Cagiltay, K. (2017). In-service preschool teachers' thoughts about technology use in early educational settings. Contemporary Educational Technology, 8(2), 119141. https://doi.org/10.30935/cedtech/6191

Kerckaert, S., Vanderlinde, R., \& Braak, J. (2015). The role of ICT in early childhood education: Scale development and research on ICT use and influencing factors. European Early Childhood Education Research Journal, 23(2), 183-199. https://doi.org/10.1080/1350293X.2015.1016804

Lavidas, K., Gialamas, V. (2019). Adaption and psychometric properties of the short forms Marlowe-Crowne social desirability scale with a sample of Greek university students. European Journal of Education Studies, 6(8), 230239. https://doi.org/10.5281/zenodo.3552531

Lavidas, K., Katsidima, A., Theodoratou, S., Komis, V., \& Nikolopoulou, K. (2021). Preschool teachers' perceptions about TPACK in Greek educational context. Journal of Computer in Education. https://doi.org/10.1007/s40692021-00184-X

Linder, S., Powers-Costello, B., \& Stegelin, D. (2011). Mathematics in early childhood: Research-based rationale and practical strategies. Early Childhood Educational Journal, 39(1), 29-37. https://doi.org/10.1007/s10643-0100437-6

Liu, X., Toki, E., \& Pange, J. (2014). The use of ICT in preschool education in Greece and China: A comparative study. Procedia - Social and Behavioral Sciences, 112, 1167-1176. https://doi.org/10.1016/j.sbspro.2014.01.1281

Ljung-Djärf, A., Aberg-Bengtsson, L., \& Ottosson, T. (2005). Ways of relating to computer use in preschool activity. International Journal of Early Years Education, 13(1), 29-41. https://doi.org/10.1080/09669760500048295

NCTM [National Council of Teachers of Mathematics]. (2015). Strategic use of technology in teaching and learning mathematics. https://www.nctm.org/uploadedFiles/ Standards and Positions/Position Statements/Strategic\% 20Use\%20of\%20Technology\%20July\%202015.pdf

Nikolopoulou, K. (2014). Educational software use in kindergarten. In C. Karagiannidis, P. Politis, \& I. Karasavvidis (Eds.), Research on e-learning and ICT in Education: Technological, Pedagogical and Instructional Perspectives (pp. 39-57). Springer. https://doi.org/10.1007/ 978-1-4614-6501-0

Nikolopoulou, K. (2020). Preschool teachers' practices of ICT Supported early language and mathematics. Creative Education, 11, 2038-2052. https://doi.org/10.4236/ ce.2020.1110149 
Nikolopoulou, K., \& Gialamas, V. (2015). Barriers to the integration of computers in early childhood settings: Teachers' perceptions. Education and Information Technologies, 20, 285-301. https://doi.org/10.1007/s10639013-9281-9

Nikolopoulou, K., Gialamas, V., Lavidas, K., \& Komis, V. (2021). Teachers' readiness to adopt mobile learning in classrooms: A study in Greece. Technology, Knowledge and Learning, 26, 53-77. https://doi.org/10.1007/s10758-02009453-7

Outhwaite, L.A., Gulliford, A., \& Pitchford, N.J. (2017). Closing the gap: Efficacy of a tablet intervention to support the development of early mathematical skills in UK primary school children. Computers \& Education, 108, 43-58. https://doi.org/10.1016/j.compedu.2017.01.011

Papadakis, S. (2015). The use of ICT for teaching realistic mathematics in preschool education. University of Crete, Rethimno. https://thesis.ekt.gr/thesisBookReader/id/ 36766\#page/2/mode/2up

Papadakis, S., Kalogiannakis, M., \& Zaranis, N. (2018). The effectiveness of computer and tablet assisted intervention in early childhood students' understanding of numbers. Education and Information Technologies, 23, 1849-1871. https://doi.org/10.1007/s10639-018-9693-7

Plowman, L., \& Stephen, C. (2005). Children, play and computers in preschool education. British Educational Research Association, 36(2), 145-157. https://doi.org/ 10.1111/j.1467-8535.2005.00449.x
Romero-Tena, R., Lopez-Lozano, L., \& G. Puig (2020). Types of uses technologies by Spanish early childhood teachers. European Journal of Educational Research, 9(2), 511-522. https://doi.org/10.12973/eu-jer.9.2.511

Sabanci, A., \& Omeroglu, M. (2015). Preschool teachers’ views and experiences about ICT use in instruction: A case study. International Journal of Academic Research in Business and Social Sciences, 5(6), 170-183. https://doi.org/10.6007/ IJARBSS/v5-i6/1667

Sanchez, A., Marcos, J., Gonsalez, M, \& GuanLin, H. (2012). In service teachers' attitudes towards the use of ICT in the classroom. Procedia - Social and Behavioural Sciences, 46, 1358-1364. https://doi.org/10.1016/j.sbspro.2012.05.302

Theodoropoulou, I., Lavidas, K., \& Komis, V. (2021). Results and prospects from the utilization of educational robotics in Greek schools. Technology, Knowledge and Learning. https://doi.org/10.1007/s10758-021-09555-w

Tsirmpa, C., Stellakis, N., Lavidas, K. (2021). Beliefs of parents of preschool children about literacy: Facilitative and Conventional approaches. European Early Childhood Education Research Journal, 29(4). https://doi.org/10.1080/1350293X.2021.1941169

Zaranis, N. (2014). The use of ICT in kindergarten for teaching addition based on realistic mathematics education. Educational and Information Technologies, 21, 589-606. https://doi.org/10.1007/s10639-014-9342-8

Zaranis, N., \& Valla, V. (2019). Tablets in learning mathematics for kindergarten students. In L. Daniela (Ed.), Didactics of smart pedagogy. Springer, Cham. https://doi.org/10.1007/978-3-030-01551-0_14 


\section{APPENDIX}

1. Teaching Mathematics

a. Do you teach mathematics in your program? If so, even a few times.

b. What mathematical concepts do you teach?

c. How many times a week?

d. If not, why?

2. ICT integration in class for teaching mathematics

a. Do you know educational software that can be used in general in the educational process, in the free and non-free hours of the daily program?

b. Do you know educational software that can be used to teach mathematics?

c. If so, which;

d. Have you tried any of them (and which ones) to use to teach math in your classroom?

e. If so, even a few times, please describe to us an approach to using educational software in teaching mathematics.

f. If not, why?

g. What mathematical concepts do you think can be taught with the help of these educational software?

3. Benefits about the use of educational software in teaching mathematics

a. Did you notice if there was a learning benefit for the students and if so in which concepts?

4. Barriers to the use of educational software for teaching mathematics

a. If you do not use educational software to teach mathematics. Do you think that mathematics could be taught with the support of some educational software?

b. If so, what is needed for this?

c. If not, what do you think are the reasons that cannot be used in teaching mathematics?

We closed the interview:

How many children do you have in your class?

Have you ever been trained to teach mathematics?

Do you have certification for the ICT integration in the educational process? 